\title{
17. THEORIZING ADULT EDUCATION, POWER AND SOCIO-ENVIRONMENTAL CHANGE
}

\author{
A Consideration of the Climate Justice Movement
}

In this chapter, we theorize power, adult education and possibilities for socioenvironmental change in terms of three theoretical concepts: intersectionality, positionality and place. Our theoretical understanding stems from our experience within the climate justice movement, specifically the Indigenous and popular resistance to the Kinder Morgan Trans Mountain Expansion Project in Canada (Cecco, 2018; Shea, 2016). This project involves adding a second pipeline alongside an existing oil pipeline running from the tar sands of Alberta across Indigenous lands to metropolitan Vancouver, British Columbia (B.C.), and into the traditional unceded territories and waters of the Indigenous nations of $x^{w} m \partial \theta k^{w} \partial y$ yom (Musqueam), Skw $\underline{x} w u$ umesh (Squamish) and Skkililwkta (Tsleil-Waututh). The opposition is led by Indigenous 'protectors' of the land and water, who see pipeline construction as a violation of sovereign land and Earth rights, in a long, continuing history of colonization, dispossession and violence by the Canadian state. Both authors of this chapter live in Vancouver as uninvited guests on unceded Musqueam territory and are involved in opposition to the pipeline. Pierre is a Euro-Amero-Canadian white man; Jenalee is a white Euro-American woman. We use our experience within this opposition movement to explain intersectionality, positionality, power and place, and propose a theoretical frame that draws on Indigenous feminism, decolonizing education and environmental justice to understand adult education for socio-environmental change.

Since the pipeline project was approved by the Canadian government in 2016, it has met with strong resistance from First Nations, the B.C. provincial government, local municipalities, and climate justice activists within Canada and the U.S. The opposition views the pipeline as a dire threat to marine life, ecosystems, inland and coastal waterways, and the health and safety of communities, while also citing the impacts it will have on climate change. However, most fundamentally, Indigenous communities are resisting what they see as an active project of continued colonization violating Indigenous land rights and sovereignty. Indigenous communities, settlercolonial activists and others have undertaken a variety of actions to resist the pipeline, from legal battles and political campaigning to direct action and civil disobedience. Resistance to the pipeline intensified in March, 2018, when members of the Tsleil-Waututh Nation announced intentions for a more direct approach to 
action at the pipeline terminus in Burnaby, B.C. At the time, Ta'ah (grandmother) Amy George, a Tsleil-Waututh elder, called on "all my relations" to "warrior up, to resist on a new level, to take care of "the whales, and the salmon, the seal, the clams, the oysters", and to speak up for "the living things that can't speak for themselves" (Lambert, 2018). Following this, a cedar Kwekwecnewtxw (traditional Watch House) was built on Burnaby Mountain to defend this sacred site, act as a spiritual centre of resistance, teach others, and watch for enemies. The Watch House has since become a centrepiece for a community of resistance: it holds space on the land, hosts land protectors, community gatherings, rallies and regular non-violent direct actions often involving road blockades and arrests (Protect the Inlet, 2018).

Standing alongside one another in blockades, marches and rallies, activists learn about the diverse causes that have moved people to action. In volunteer orientations and trainings, they learn about their legal rights, the logistics of organizing, and the power of peaceful, non-violent collective action. By attending community events and sharing meals at the Watch House, they learn about Indigeneity and Canada's history and the continuation of colonization. Through action, individuals come to better understand and communicate their opposition to the pipeline and enhance their sense of agency. This individual learning helps to create a community of resistance which is learning to construct a peaceful, place-based counter-narrative to continued colonization by the fossil fuel industry and its allies. Beyond participation, the complex process of planning and negotiating social action - rallies, blockades, arrests, legal challenges, campaigning, press releases - requires research and information gathering, as well as communication across difference that acknowledges intersections of oppression. This process of collaboration leads to both individual transformative learning, and collective learning and group consciousness.

\section{INTERSECTIONALITY, POSITIONALITY, PLACE AND POWER}

The concepts of intersectionality, positionality and place help us to understand the relational, situated complexities of power and privilege in the adult learning, education and knowledge created through the community of resistance. First, we turn to theorizing on interlocking structures of power and oppression along lines of race, class, gender, and sexuality proposed early on by black feminist Kimberlé Crenshaw (1989) and debated by many others. Intersectionality continues to be taken up in theoretical debates in adult education (Merrill \& Fejes, 2018; Verjee \& Butterwick, 2014), ecofeminism (Gaard, 2011; Kings, 2017) and in research on climate change (Kaijser \& Kronsell, 2014). The concept of intersectionality helps us to recognize how various forms of social stratification combine and act to simultaneously marginalize, degrade and disempower particular groups of people. The lived experiences of oppression for people like women of color, Indigenous Peoples, Queer men, Muslims, and so on will be not only be qualitatively different for each, but will intersect across diverse lines of identities, both those proudly embraced by individuals and those imposed upon them by society. 
In scholarship on climate justice, Kaijser and Kronsell (2014, p. 421) note that "from an intersectional understanding, how individuals relate to climate change depends on their positions in context-specific power structures based on social categorizations": climate change and environmental racism will have different ways of impacting poor and racialized people. In the Trans Mountain pipeline resistance, diverse Indigenous and non-Indigenous activists - urban, rural, women, men, straight, queer, transgender, white, racialized, poor and well-off, young and old are pulled together and collectively call for Indigenous rights, social and climate justice, and a halt to pipeline construction. All will have diverse and intersecting social and cultural identities, and will differentially experience these in a "matrix of domination" (Collins, 2014, p. 21). Indigenous women's experience of power, for instance, differs significantly from non-Indigenous women, Indigenous men, and other social groups within the movement, and accordingly affects what and how they learn and teach others (Grande, 2004; Green, 2007). Indigenous women opposing the pipeline experience intersecting oppressions as they fight for climate justice, and against capitalism, patriarchy, racism and classism, all the while resisting colonialism. Their relational responsibilities to the Earth, to place, and their communities is a duty they assume in regard to specific relations (water, birds, plants, fish, etc.) within a web of responsibilities vital to their communities (Whyte, 2014). Their ability to uphold their relational responsibilities to the Earth are severely and directly impacted by climate change, environmental degradation and projects like the Trans Mountain pipeline. Others, such as the many queer and transgender activists who have joined the protests, experience intersections of power, place and learning differently. Straight white activists and Indigenous elders in their 60, 70s and 80 s again have a different, complex positionality in relation to younger activists and decolonizing education.

In the Trans Mountain opposition, each activist and organizer contributes knowledge, information, and a sense of commitment that stems from their own sociocultural experience learned through their positionality. In this way, the potential for individual and collective learning depends on difference. Diverse positionalities serve as tools for learning as the group negotiates a collective identity, generates group consciousness, and organizes in solidarity (Kilgore, 1999). Learning takes place in the opposition as activists and organizers negotiate the means of social action, and depending on the success or failure of strategies and tactics, revaluate and further strategize according to the social, political, and historical context. This process brings clarity to and raises consciousness of power structures inside the movement as the movement discerns who should be centred in strategy and tactics of social action, as well as beyond the movement as organizers and activists come to understand the allies and enemies these power structures create. For example, organizers may encourage older white, rich men to risk arrest rather than young Indigenous women, knowing that one may be treated differently than the other in the courts, or be better able to take on the social and economic repercussions of imprisonment or more easily carry a criminal record. Similarly, elderly women are 
fronted in actions and blockades when law enforcement is trusted to be civil and when leaders want to appeal to public sympathy by centring innocent, law abiding 'grannies'. In both cases, positionality is essential to strategic action. The process of organizing and taking action demands individual reflection on positionality and larger power structures, as well as group reflexivity in relation to context. Both are essential to adult learning where there is a need to 'deconstruct positionality's epistemology', to disrupt dominant narratives, structures and stereotypes, and to replace these with situated counter-knowledges and counter-narratives (Kaijser \& Kronsell, 2014; Misawa, 2010).

When we consider the concept of place in adult environmental education, the theoretical picture becomes even more complex. Here we begin to trouble contemporary theorizing in adult education to consider the inclusion of Earth rights and an Earth-centred positionality in relation to questions of democracy, equality and power, and to new possibilities for adult education. That is, we understand inequality, power, privilege, adult education and climate justice as existing in a complex, diverse and interdependent world, yes, but we take this world to include not just human beings and human societies, but all our living and non-living relations and communities as well. We must understand not only intersections, positionalities and relations among adult educators and others, but also the rights of Mother Earth, of animals, plants, rocks, streams, fields and mountains (i.e., all our relations). As such, we must adopt an Earth-centred positionality to understand the many forms of oppression, inequality, abuse and violence, along intersecting axes of power and positionality, done by humans to Mother Earth. An earth-centred positionality counters anthropocentrism, 'speciesism' and 'humanism', on the one hand, and supports ecocentrism, agency, the rights of nature, animal rights, inter-species relations, and the interconnectedness of all beings and the Earth, on the other.

These and similar ideas have since the 1970s been theorized in deep ecology and ecofeminism, more recently in Critical Animal Studies, Environmental Humanities and climate justice scholarship (e.g. Gaard, 2011; Tola, 2018; Weitzenfeld \& Joy, 2014), and have always been present in Indigenous epistemologies. They might now be introduced into adult education to good effect. To this end, deep ecology, for example, calls for education to shift human consciousness away from individual ego and anthropocentrism (i.e. the 'I-self') towards an understanding of the interconnectedness, interdependence and equal value of all life on earth (the 'weself'; the 'eco-self') (Haigh, 2006). This shift involves a 'deep' questioning of human life and the causes of environmental destruction, the cultivation not only of scientific knowledge, but also of intuitive, spiritual and emotional knowledge of ourselves and the Earth ('Gaia'), and a recognition of the imperative to change our behaviours and take action to protect the earth from human harm (Drengson, Devall, \& Schroll, 2011). Ecofeminism adopts similar principles, but underscores the connection between the exploitation of nature and the exploitation of women, and links to patriarchy, racism, colonialism and classism (Gaard, 2011). Moreover, ecofeminism conceives of Mother Earth not as a collection of individual organisms 
(as in deep ecology), but as communities of related beings (Stevens, Tait, \& Varney, 2018), much in the same manner as Indigenous Peoples do.

From Indigenous perspectives, it is important to recognize that Mother Earth is not a metaphor, and not just "an essential part of the conception of (Indigenous Knowledge) ..., it is the lives lived by people and their particular relationship with Creation" (McGregor, 2004, p. 390). From this perspective, all environmental adult education is fundamentally learning about self and identity, as we belong to, and are inextricably a part of Mother Earth. Notably, this is not to reinforce the historical trope of 'Noble Savage' or reify present-day stereotypes of 'Ecological Indians' (Freidel, 2011). Indigenous Peoples are not homogenous, nor do they all live in unchanging 'ancient' societies close to nature; our point is only that Earth-centred Indigenous epistemologies and ontologies are as close as we humans come to an Earth-centred positionality.

\section{INDIGENOUS FEMINISM, ENVIRONMENTAL JUSTICE AND DECOLONIZING EDUCATION}

How then do notions of power, privilege and socio-environmental change play out in an Earth-centred positionality of place in environmental adult education? Since we as urbanized, colonized human beings have removed ourselves so thoroughly from being able to listen to and seek advice directly from the Earth (nor could we represent knowledge gained this way in textual form), we have no choice but to turn to human theorizing once more. Here, we look to Indigenous feminism, environmental justice, and decolonizing education for guidance.

From theoretical work in Indigenous feminism, we understand that although Indigenous identities, societies and peoples are traditionally of Mother Earth, and have a history of working within an equitably differentiated gendered division of labor, and while both Indigenous men and women have been subject to genocidal colonial histories, dispossession of land and culture, White Supremacy and racism, Indigenous women also suffer additionally from systems of colonial-induced patriarchy cutting across indigeneity. That is, "Indigenous women have endured a double erasure (and marginalisation) - first, as Indigenous peoples, and secondly, as women" (Grande, 2004, p. 127). Thus, while maintaining an Earth-based positionality, Indigenous feminism seeks to identify and resist "the ways in which (Indigenous) women are subordinated to men and how women can be emancipated from this subordination" (Green, 2007, p. 21).

Decolonizing education requires, first, the historical study of the human systems of oppression - settler colonialism, capitalism, patriarchy, systemic racism - which have destroyed Mother Earth and dispossessed Indigenous Peoples of their basic human rights to land, culture and livelihood. Second, it normally demands a recognition of direct personal complicity in these acts, not only by all present-day settlercolonial peoples living on stolen lands (e.g. Canada, U.S. Japan, China, Australia, all of Latin America, Africa), but also by those residing in colonial states built upon 
these genocidal and environmentally catastrophic histories (England, Spain, France, Belgium, Italy, Netherlands, Portugal). An 'Earth-centred conscientization' of adult learners continues through the histories and lived realities of Indigenous, poor, and racialized people bearing the costs of toxic waste, polluted water, and climate change; that is, of environmental racism, classism and oppression (Irlbacher-Fox, 2014). Third, decolonizing education recognizes that Indigenous Peoples have been defending the Earth and their very lands, lives, cultures, livelihood, human rights and identity against the violent onslaught of colonialism continuously for almost 600 years, continue to struggle today for the restoration of stolen ancestral lands, and are actively working to recover scared sites and cultural knowledge ripped away from them by non-Indigenous People (Tuck \& Yang, 2012). Finally, with this historical consciousness in place, the question becomes how to re-establish a personal relationship with Mother Earth for all peoples (Plumwood, 2003), and for non-Indigenous people, how to develop a respectful and humble relationship with Indigenous Peoples, who are at once our teachers and 'co-resisters' as well as co-advocates for the return of stolen lands, the struggle against climate injustice, capitalism, racism and patriarchy, and the struggle for reconciliation and the healing of the Earth.

The Tsleil-Waututh Nation leading the movement against Trans Mountain are Sklililwkta or 'People of the Inlet': they are among the people most directly impacted by the pipeline construction and potential oil spills. As people of the water, protection of the water is not simply a moral or ethical mandate, it is protection of self, of identity and existence, as well as a spiritual duty. Yet all Tsleil-Waututh people do not experience their relationship to the water and the powers that threaten it in the same way: intersections of gender, "kinship, age, wealth, race, religion, political situation, and other characteristics affect and frame what one experiences as an indigenous person" (Whyte, 2014, p. 604), just like any other.

The positionality of Indigenous women within Tsleil-Waututh culture grants them particular understandings, identities, relations and responsibilities to water, similar to those they might have to children, elders or other family members. Starting with water in the womb, water is thought of as life-giving and life-sustaining, and as such, women have a special duty to protect this relation. Of course, not all Indigenous women take up this responsibility, but elders acting as leaders of the movement often speak of this connection. When Indigenous women within the movement talk of their sacred duty to protect the water, they speak of it quite differently from nonIndigenous women or others who might see water as life-sustaining, but not as a living relation. These different positionalities both embody and create different types of learning and knowledge generation and exchange within and from the movement. A non-Indigenous woman may resist the pipeline to protect the water as a social or moral responsibility, while an Indigenous woman struggles against colonial ideas that challenge her ability to do her spiritual or cultural duty to a relation (water). Thus, for a non-Indigenous woman, protecting the water may bring about social or environmental consciousness, while for an Indigenous woman, it may support 
cultural learning and reconnection to spiritual practice. In the same sense, abuses of power, marginalization and oppression are not experienced by non-Indigenous women (or men) in quite the same way. However, by working side-by-side in the movement, these adults co-enact a decolonizing education, learning from each other, questioning, revealing, undoing and replacing the hegemony of colonial truths with new knowledge of Indigenous history, epistemologies, colonialism, Earth-centred positionality and relations. Decolonizing education places human identity and social action into a web of both human and non-human relations - water, land, air, plants, animals - who cannot then be considered exploitable natural 'resources', and whom we are obligated to protect from harm (Adams, 2003). Thus, 'water protector' becomes not only a name, but also an identity, a relation, a sacred duty, and a way of being. Centering Indigenous voices and leadership, activists and organizers are able to reflect on differences of oppression, identity, and ways of being, as well as their roles within the movement and their own positioning as part of the collective 'we' in relation to place.

Non-Indigenous climate justice activists in B.C. also have strong ties to land and water, sea and sky, based on livelihood, life history, spirituality and identity. Some depend on agricultural production, fishing or coastal tourism to support themselves. Many feel a deep spiritual connection to the immense beauty of B.C.'s landscapes and wild spaces; others value the opportunities afforded by the land and sea for hiking, kayaking, skiing, hunting, camping, boating or fishing. Some ties are shallow, some deep, some cultural, others spiritual or material. Some believe in rights to property and ownership; others see open, un-owned lands for all. However, in learning to see through a decolonizing lens, these and other adults in the movement begin to better understand the situated nature of power in relation to place and Indigenous Peoples. New knowledge uncovers our colonial mindset toward the Earth, where people's relations with nature are controlled by oil companies, governments, courts, rich white men, etc. working against, rather than with, nature (Adams, 2003). Through a decolonizing lens, this knowledge is not limited to the present -where the fossil fuel industry is controlling relationships to land with implications for human and non-human futures - but also extends to the past teaching lessons of the reality of colonization that has controlled Indigenous communities' relationships to the land for hundreds of years.

Positionality in relation to place is complex and varied among adults, in part depending on the extent to which their livelihood is place-based. For some, the Trans Mountain project is understood as both an immediate and future threat to ocean- and land-based livelihood because of oil spills, tanker traffic through marine ecosystems, and the effects of climate change, including sea level rise, acidification and warming. An understanding of environmental justice as integral to decolonizing education highlights these and other positionalities. Wealth, power and education may allow some to shift livelihood in the case of an oil spill or sea levels rise; poorer coastal fishing communities may not have the means to do so. A non-Indigenous organizer working in the coastal tourism industry may be more directly threatened 
by the pipeline than an Indigenous woman professional working in an urban office, and so on. The threat of the pipeline is experienced and learned differently culturally, socially, spiritually and economically - depending on the intersects of social categories and positionality within the larger power structures in connection to place. Indigenous and non-Indigenous activists, for example, differ somewhat in their perspectives of the Earth's role within the movement. Some colonial-settler activists, talking of protecting the non-human world (waterways, orcas, salmon, etc.), frame the Earth as a separate entity, and something to be guarded. By contrast, Indigenous leaders not only speak of a responsibility to protect their relations, but also acknowledge the non-human world's participation in the struggle. This is done in ways as simple as recongizing the presence of trees, birds, animals, and plants in the everyday events and activities of resistance. It might mean drawing attention to eagles flying overhead who are watching over protest marches and rallies, or, before a protest action, acknowledging the history of a place; not only human histories, but also histories of other beings. In this way, the non-human world is included in the movement rather than simply being a beneficiary of it, giving voice to 'all our relations', not just human voices. These recognitions and inclusions provide moments of learning where activists and organizers are encouraged to question colonial conceptions of a separate non-human world.

Through learning from Indigenous leadership, the Earth and non-human relations are moved from the margins to "take their place as narrative subjects in a speaking and participating land, full of narratives and mythic voices" (Plumwood, 2003, p. 67). Inviting the Earth to be part of the conversation teaches an Earth-centred positionality, facilitated by Indigenous leaders and others who recognize the Earth's agency and challenge a colonial 'deafness' to the non-human world (Plumwood, 2003). In doing so, they begin a decolonizing dialogue in environmental adult education in which the Earth is an inseparable part of adult learning and education, culture, community, identity and human existence.

\section{REFERENCES}

Adams, W. (2003). Nature and the colonial mind. In W. M. Adams \& M. Mulligan (Eds.), Decolonizing nature: Strategies for conservation in a post-colonial era (pp. 16-50). London: Earthscan.

Cecco, L. (2018, May 29). Kinder Morgan pipeline: Canadian government to buy project for $\$ 4.5 \mathrm{bn}$. The Guardian. Retrieved from https:/www.theguardian.com/world/2018/may/29/canada-kinder-morganpipeline-trans-mountain

Colin, S. A., \& Lund, C. L. (2010). The intersections of white privilege and racism: Moving forward. New Directions for Adult and Continuing Education, 125, 91-94.

Collins, J. C., \& Taborda-Whitt, C. (2017). Disrupting human resource development to see, hear, and value queer people of color: A call to action. New Horizons in Adult Education and Human Resource Development, 29(1), 1-4.

Collins, P. H. (2014). Black feminist thought: Knowledge, consciousness, and the politics of empowerment (Revised 10th anniversary ed.). New York, NY: Routledge.

Crenshaw, K. (1989). Demarginalizing the intersection of race and sex: A Black feminist critique of antidiscrimination doctrine, feminist theory and antiracist politics. University of Chicago Legal Forum, 140, 139-167. 


\section{THEORIZING ADULT EDUCATION, POWER AND SOCIO-ENVIRONMENTAL CHANGE}

Drengson, A., Devall, B., \& Schroll, M. A. (2011). The deep ecology movement: Origins, development, and future prospects (toward a transpersonal ecosophy). International Journal of Transpersonal Studies, 30(1), 101-117.

Dhillon, C., \& Young, M. G. (2010). Environmental racism and First Nations: A call for socially just public policy development. Canadian Journal of Humanities and Social Sciences, 1(1), 25-39.

Friedel, T. L. (2011). Looking for learning in all the wrong places: Urban Native youths' cultured response to Western-oriented place-based learning. International Journal of Qualitative Studies in Education, 24(5), 531-546.

Gaard, G. (2011). Ecofeminism revisited: Rejecting essentialism and re-placing species in a material feminist environmentalism. Feminist Formations, 23(2), 26-53.

Grande, S. (2004). Red pedagogy: Native American social and political thought. Lanham, MD: Rowman \& Littlefield.

Green, J. (2007). Making space for indigenous feminism. London: Zed Books.

Haigh, M. (2006). Deep ecology education: Learning from its Vaisnava roots. Canadian Journal of Environmental Education, 11(1), 43-56.

Haig-Brown, C. (2009). Decolonizing diaspora: Whose traditional land are we on? Cultural and Pedagogical Inquiry, 1(1), 4-21.

Hall, B. L. (2009). A river of life: Learning and environmental social movements. Interface: A Journal for and About Social Movements, 1(1), 46-78.

Harding, (2003). The feminist standpoint theory reader: Intellectual and political controversies. New York, NY: Routledge.

Irlbacher-Fox, S. (2014). Traditional knowledge, co-existence and co-resistance. Decolonization: Indigeneity, Education \& Society, 3(3), 145-158.

Kaijser, A., \& Kronsell, A. (2014). Climate change through the lens of intersectionality. Environmental Politics, 23(3), 417-433.

Kilgore, D. W. (1999). Understanding learning in social movements: A theory of collective learning. International Journal of Lifelong Education, 18(3), 191-202. doi:10.1080/026013 799293784

Kinder Morgan. (2017). Trans Mountain: Project overview. Retrieved from http://www.transmountain.com/project-overview

Kings, A. E. (2017). Intersectionality and the changing face of ecofeminism. Ethics \& the Environment, $22(1), 63-87$.

Lambert, S. (2018). The Warrior Song of Ta'ah Amy George. National Observer. Retrieved from http://www.nationalobserver.com/2018/04/28/opinion/warrior-song-taah-amy-george

McGregor, D. (2004). Coming full circle: Indigenous knowledge, environment, and our future. American Indian Quarterly, 28(3-4), 385-410.

Merrill, B., \& Fejes, A. (2018). Intersectionality and adult education. European Journal for Research on the Education and Learning of Adults, 9(1), 7-11.

Misawa, M. (2010). Queer race pedagogy for educators in higher education: Dealing with power dynamics and positionality of LGBTQ students of color. The International Journal of Critical Pedagogy, 3(1), 26-35.

Nocella, A. J., Sorenson, J., Socha, K., \& Matsuoka, A. (2014). Introduction: The emergence of critical animal studies: The rise of intersectional animal liberation. Counterpoints, 448, xix-xxxvi.

Pellow, D. N. (2016). Toward a critical environmental justice studies: Black lives matter as an environmental justice challenge. Du Bois Review: Social Science Research on Race, 13(2), 221-236.

Plumwood, V. (2003). Decolonizing relationships with nature. In W. M. Adams \& M. Mulligan (Eds.), Decolonizing nature: Strategies for conservation in a post-colonial era (pp. 51-78). London: Earthscan.

Protect the Inlet. (2018). Kwekwecnewtxw - The watch house. Retrieved from https://protecttheinlet.ca/ structure/

Shea, S. M. (2016). Caretakers of the mountain: Understanding the Burnaby Mountain Pipeline Blockade (Doctoral dissertation). School of Criminology, Simon Fraser University, Vancouver, Canada.

Stevens, L., Tait, P., \& Varney, D. (Eds.). (2018). Feminist ecologies: Changing environments in the Anthropocene. Cham: Palgrave. 


\section{P. WALTER \& J. KLUTTZ}

Tola, M. (2018). Between Pachamama and mother earth: gender, political ontology and the rights of nature in contemporary Bolivia. Feminist Review, 118(1), 25-40.

Tuck, E., \& Yang, K. W. (2012). Decolonization is not a metaphor. Decolonization: Indigeneity, Education \& Society, 1(1), 1-40.

Verjee, B., \& Butterwick, S. (2014). Conversations from within: Critical race feminism and the roots/ routes of change. In S. Iverson \& J. James (Eds.), Feminist community engagement (pp. 31-51). New York, NY: Palgrave Macmillan.

Weitzenfeld, A., \& Joy, M. (2014). An overview of anthropocentrism, humanism, and speciesism in critical animal theory. Counterpoints, 448, 3-27.

Whyte, K. P. (2014). Indigenous women, climate change impacts, and collective action. Hypatia, 29(3), 599-616. 